\title{
Semi-arid warm-season grass yield and nutritive value in Argentina
}

\author{
NESTOR P. STRITZLER, JOSE H. PAGELlA, VARINIA V. JOUVE AND CARLOS M. \\ FERRI
}

First author is research animal scientist, Instituto Nacional de Tecnología Agropecuaria, Anguil, La Pampa, and professor, Area de Producción Animal, Facultad de Agronomia, Universidad Nacional de La Pampa. Second, third and fourth authors are research assistants, Area de Producción Animal, Facultad de Agronomía, Universidad Nacional de La Pampa, (6300) Santa Rosa, La Pampa, Argentina.

Current address of second author is: The Rowett Research Institute, Bucksburn, Aberdeen AB2 95B, Scotland.

\begin{abstract}
The use of standing dead biomass, during the winter that was produced by warm-season grasses in the previous growing season by pregnant beef cows may be an alternative to grazing systems in the semi-arid Pampean Region of Argentina. This study, conducted over 2 years, 1990 and 1991, compared the winter forage quality produced during the previous growing season for 4 warm-season grasses; switchgrass (Panicum virgatum L. cv. Pathfinder), kleingrass (Panicum coloratum L.), tetrachne (Tetrachne dregei Nees) and weeping lovegrass (Eragrostis curvula (Schrad), Nees cv. Tanganyka). Five harvests of the summer growth started after the first frost, and were spaced evenly throughout the winter period. Changes in the standing crop of dry matter were measured and subsamples of forage were divided into leaf and stem fractions. Forage quality analyses included: crude protein (CP), in vitro dry matter digestibility (IVDMD), effective rumen degradability (ED), neutral (NDF) and acid (ADF) detergent fiber and lignin. Tetrachne dregei produced forage with a higher leaf:stem ratio and of generally higher quality, than the other species, although the differences were not always significant. Its CP content was marginally below the maintenance requirements of cows. Dry matter yield of tetrachne was lower than that of weeping lovegrass, but differences were only significant in 1990. Kleingrass generally was high in quality and dry matter yield, although it was the lowest in percentage of leaves of the 4 species evaluated. Switchgrass was the least productive; the nutritive value of its forage was low, comparable or lower than that of weeping lovegrass. The first harvest date was higher in nutritive value. Although the nutritive value of leaves and stems were not compared statistically, the leaves tended to be higher than the stems. Tetrachne dregei, the best of the species evaluated in this study, is a very promising warm-season grass, which could provide nutritious forage for winter grazing systems in the semiarid Pampean Region of Argentina.
\end{abstract}

This study was supported by the International Foundation for Science, through the Research Grant Agreement B/1542-1.

We are indebted to Dr. Phillip L. Sims, Research Leader, USDA-ARS, Southem Plains Range Research Station, Woodward, Okla., who made helpful contributions through critical reviews of earlier versions of the manuscript.

Manuscript accepted 3 June 1995.
Key Words: warm-season grasses, yield, forage quality, semiarid environment, Argentina.

The semi-arid Pampean Region is characterized by highly variable annual and seasonal distribution of rainfall with a generally dry winter season (Table 1). The growth rate of temperate grasses during the winter is near zero with growth restricted to the spring, summer and fall seasons. Cool season annuals provide forage of a high quality to grazing animals, but production is more expensive. This disadvantage becomes even more important if the forage is grazed by cattle with relatively low requirements such as pregnant dry cows.

One way to provide an economical winter forage would be to use forage produced during the previous growing season, by warm-season grasses, as standing forage during the winter (Covas 1982). This forage would need to retain much of its quality in the dormant stage. Until now, in Argentina the only warm-season species that has been studied is (Eragrostis curvula (Schrad), Nees cv. Tanganyka) weeping lovegrass. However, its quality as deferred forage is low (Rabotnikof et al 1986a). The evaluation of native warm-season grasses showed that their deferred forage quality was similar to that of weeping lovegrass, but dry matter yields were much lower (Rabotnikof et al 1986a, 1986b, Stritzler unpublished results). Therefore, a warm-season grass with higher mature forage quality than weeping lovegrass, may be useful.

The aim of this study was to evaluate the amount and quality of forage produced by selected warm-season grasses recently introduced in the semi-arid Pampean Region, and to compare them with the widely used weeping lovegrass throughout the winter season.

\section{Materials and Methods}

This study was conducted in 2 years, 1990 and 1991 on the Facultad de Agronomía, Universidad Nacional de La Pampa, Santa Rosa, La Pampa, Argentina, Lat: $36^{\circ} 46^{\prime}$ S; long: $64^{\circ} 16^{\prime}$ W; $210 \mathrm{~m}$ ASL. 
Table 1. Monthly, Annual (from January to December) and Annual (from October to September next year) rainfall (in mm) for 1989, 1990, and 1991 at the Facultad de Agronomia, Universidad Nacional de La Pampa, Santa Rosa, La Pampa, Argentina.

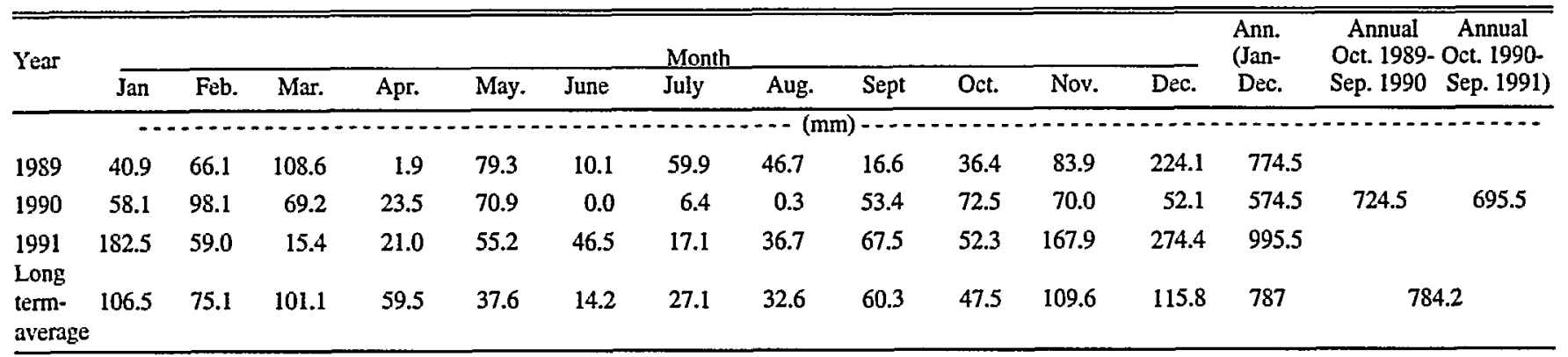

The 4 warm-season grasses evaluated of were:

1. Weeping lovegrass (Eragrostis curvula (Schrad) Nees, cv. Tanganyka)

2. Switchgrass (Panicum virgatum L. cv. Pathfinder)

3. Kleingrass (Panicum coloratum L.)

4. Tetrachne (Tetrachne dregei Nees)

Weeping lovegrass was considered as "control", as it is a well known, wide-spread forage species in our Region.

The 4 species were planted in plots of $4.20 \mathrm{~m}$ long by $2.40 \mathrm{~m}$ wide each, consisting of 4 rows spaced $0.60 \mathrm{~m}$ apart; each row consisted of 14 plants spaced $0.30 \mathrm{~m}$ apart. All the plots were planted between 27 March 1989 and 4 April 1989.

The plots were arranged into a randomized complete block design, with 5 harvest dates, spaced at approximately 1 month intervals during the winter and 3 replications for each species. The whole experiment, therefore, included 60 plots ( 4 species $\times 5$ harvest dates $\times 3$ replications).

The experimental stands of grasses were prepared for study by cutting all the plants to a uniform height of about $5 \mathrm{~cm}$ at the end of the winter season, 1989. During the growing season, weeds were controlled manually.

Harvesting was started after the first frost. Harvesting dates for the 2 years of observations were:

1. 20 April 1990, 17 April 1991

2. 18 May 1990,16 May 1991

3. 18 June 1990, 17 June 1991

4. 16 July 1990 , 15 July 1991

5. 15 August 1990, 15 August 1991

After the last harvest of the first year, the plots were fertilized with $100 \mathrm{Kg} \mathrm{N} / \mathrm{ha}$ (9 Sept. 1990).

On each harvest date, 3 plots of each species were clipped at about $5 \mathrm{~cm}$ from ground level. Total weight was recorded and a subsample of each was dried at $65^{\circ} \mathrm{C}$ for 72 hours, to estimate dry matter yields, ground through a $1 \mathrm{~mm}$ screen in a Wiley mill and stored for laboratory analyses. Another subsample of each plot was separated into leaf and stem fractions. Leaves consisted of blades, broken off at the sheath, and stems included heads, where present. After separation, both fractions were dried at $65^{\circ} \mathrm{C}$ for 72 hours, weighed to estimate the percentage of each plant part and ground and stored as described above for the whole plant.

As each harvest date included 12 plots ( 4 species and 3 replications), and 3 subsamples (leaf, stem, and whole plant) from each of them were obtained, the laboratory analyses were performed on 36 samples from each harvest date.

\section{Laboratory Analyses}

Crude protein content (CP) was determined by the semimicro Kjeldahl method $(\mathrm{N} \times 6.25)$; in vitro dry matter digestibility (IVDMD) was measured according to the method of Tilley and Terry (1963), modified by Alexander and McGowan (1966); neutral detergent fiber (NDF) and acid detergent fiber (ADF) analyses were performed as described by Goering and Van Soest (1970), and lignin content according to Christian (1971).

The samples were also incubated in sacco, in nylon bags, in the rumens of three fistulated steers. The bags, made of polyamide cloth with a mean pore size of $50 \mu$, were tightly closed with a fishing line, and bound to a rubber stopper by a self clinching tie. To maintain a relationship of $12.5 \mathrm{mg}$ dry matter $/ \mathrm{cm}^{2}$ of bag surface area, which was about $130 \mathrm{~cm}^{2}$ excluding closing area, 1.60 $\mathrm{g}$ of dry matter was included in each bag. The samples were incubated in the rumens for $72,48,36,24,16,12$, and 8 hours, and withdrawn from the rumens, cleaned under running tap water for 5 minutes and washed in a washing machine with cold water for 1 hour. Another set of 3 nylon bags containing samples were incubated in distilled water at $38^{\circ} \mathrm{C}$ for 15 minutes, to determine initial washing losses. The cleaned nylon bags were then dried at $65^{\circ} \mathrm{C}$ for 72 hours and weighed.

The effective degradability of forage in the rumen (ED) of each sample was calculated as described by McDonald (1981):

$$
E D=a+\frac{b \cdot c}{c+k} \operatorname{EXP}(-(c+k) T)
$$

where:

$$
\begin{aligned}
\text { ED } & =\text { effective degradability } \\
a & =\text { initial washing loss } \\
b & =\text { potential degradation } \\
c & =\text { degradation rate } \\
k & =\text { rumen outflow rate (given) } \\
T & =\text { time (in hours) }
\end{aligned}
$$

\section{Stastical Procedure}

The results for each parameter measured were statistically treated, within year and plant part, by analysis of variance. Means with significant differences were compared using Tukey's test (Sokal and Rohlf 1979).

\section{Results and Discussion}

\section{Comparison Between Species}

The amount of mature standing forage over the winter period for both years of the study averaged from $5,442 \mathrm{~kg} / \mathrm{ha}$ for switch- 
Table 2. Dry matter yield (in $\mathrm{kg} / \mathrm{ha}$ ) of whole plant, percentage of leaves and leaf:stem ratio, on dry matter basis, of 4 warm-season grasses (means of 5 harvest dates).

\begin{tabular}{|c|c|c|c|c|c|c|c|c|c|}
\hline \multirow{3}{*}{ Species } & \multicolumn{6}{|c|}{ Ycar } & \multicolumn{3}{|c|}{ Average } \\
\hline & \multicolumn{3}{|c|}{1990} & \multicolumn{3}{|c|}{1991} & \multirow[b]{2}{*}{$\begin{array}{c}\text { Dry } \\
\text { matter }\end{array}$} & \multirow[b]{2}{*}{ leaves } & \multirow[b]{2}{*}{$\begin{array}{l}\text { leaf: } \\
\text { stem }\end{array}$} \\
\hline & $\begin{array}{l}\text { Dry } \\
\text { matter }\end{array}$ & leaves & $\begin{array}{l}\text { leaf: } \\
\text { stem }\end{array}$ & $\begin{array}{c}\text { Dry } \\
\text { matter }\end{array}$ & leaves & $\begin{array}{l}\text { leaf: } \\
\text { stem }\end{array}$ & & & \\
\hline $\begin{array}{l}\text { Weeping } \\
\text { lovegrass }\end{array}$ & $\begin{array}{l}(\mathrm{kg} / \mathrm{ha}) \\
10081^{2}\end{array}$ & $\begin{array}{l}(\%) \\
47.1^{\mathrm{a}}\end{array}$ & 0.89 & $\begin{array}{l}(\mathrm{kg} / \mathrm{ha}) \\
10182^{2}\end{array}$ & $\begin{array}{c}(\%) \\
44.1^{\mathrm{a}}\end{array}$ & 0.79 & $\begin{array}{l}(\mathrm{kg} / \mathrm{ha}) \\
10132\end{array}$ & $\begin{array}{l}(\%) \\
45.6\end{array}$ & 0.84 \\
\hline Switchgrass & $3874^{b}$ & $30.0^{\mathrm{C}}$ & 0.43 & $7099^{\mathrm{a}}$ & $34.1^{\mathrm{b}}$ & 0.52 & 5442 & 32.1 & 0.48 \\
\hline Kleingrass & $8552^{a}$ & $13.2^{d}$ & 0.15 & $8096^{a}$ & $19.1^{c}$ & 0.24 & 8324 & 16.2 & 0.20 \\
\hline Tetrachne & $5294^{b}$ & $39.0^{b}$ & 0.64 & $7252^{a}$ & $43.8^{2}$ & 0.78 & 6213 & 41.4 & 0.71 \\
\hline
\end{tabular}

Values within a column, followed by different letter are significantly different $(\mathrm{P}<0.05)$.

grass to a high of over $10,000 \mathrm{~kg} / \mathrm{ha}$ for weeping lovegrass. In general, weeping lovegrass produced the most forage, kleingrass second, tetrachne third and switchgrass the least (Table 2). The differences in standing forage over the winter were significant $(\mathrm{P}<0.05)$ only for the 2 most productive grasses compared to the 2 other grasses during the first year of the study only. There were no significant differences in herbage yields in 1991 even though, yields ranged from about 7,100 to over $10,000 \mathrm{~kg} / \mathrm{ha}$.

The average annual, winter and summer temperatures at the study site were $15.6,8.4$, and $22.7^{\circ} \mathrm{C}$, respectively.

Total annual rainfall varied from a low $574.5 \mathrm{~mm}$ in 1990 to 995.5 in 1991 (Table 1). This compares to $787 \mathrm{~mm}$ of longterm annual average rainfall collected at Facultad de Agronomía, Universidad Nacional de La Pampa. The difference between the 2 study years, 1990 and 1991, was considerably less if the rainfall is summed over a "crop year" that begins in October and runs through September of the following year. Moreover, considering a "crop year", the annual rainfall of 1990 and 1991 were not far from the longterm average (Table 1).

Over both study years, percentage of the leaves ranged from a low of $16 \%$ for kleingrass to over $40 \%$ of the dry matter in leaves for weeping lovegrass and tetrachne. There were significant differences in the percent leaves for the 4 grasses studied. In 1990 these differences were significant between each of these species $(\mathrm{P}<0.05)$. During 1991 there were no differences in percent leaves between weeping lovegrass and tetrachne but there were differences between these 2 grasses and switchgrass which had $34.1 \%$ leaves, and kleingrass which had $19.1 \%$ leaves.

The statistical significance of differences between the forage species and the error mean squares can be seen in Table 3.

Tetrachne dregei generally had the highest forage quality characteristics measured in this study. The CP content was highest $(P<0.05)$ in tetrachne and lowest in switchgrass for all fractions, in both years, although some of the differences were not significant (Tables 3 and 5).

For all plant fractions, in both years, IVDMD of tetrachne was significantly higher $(\mathrm{P}<0.05)$ than that of weeping lovegrass and switchgrass. The IVDMD of kleingrass was also higher $(\mathrm{P}<0.05)$ than the values of weeping lovegrass and switchgrass, for all plant fractions in 1991 and for stem and whole plant in 1990. Stem digestibility for tetrachne and kleingrass ranged from 50 to $55 \%$ early in the winter season to between 45 and $50 \%$ by the end of the winter period. The stem and whole plant fractions effective rumen degradability (ED) values were highest for kleingrass and tetrachne and lowest for weeping lovegrass. The effective degradability (ED) of leaves was highest for switchgrass $(\mathrm{P}<0.05)$ and lowest for weeping lovegrass.

The NDF content of leaves was highest in weeping lovegrass and lowest in switchgrass and kleingrass $(\mathrm{P}<0.05)$. The percentage of NDF of the stem fraction, on the other hand, was higest in switchgrass and lowest in kleingrass $(\mathrm{P}<0.05)$. The NDF content of the whole plant was higher for weeping lovegrass and switchgrass than for kleingrass and tetrachne $(\mathrm{P}<0.05)$. The percentage of ADF was highest for all fractions, in both years, in switchgrass $(\mathrm{P}<0.05)$, while tetrachne tended to have the lowest values.

The lignin content of tetrachne averaged $5.66 \%$ across both years and was significantly lower than weeping lovegrass and switchgrass $(\mathrm{P}<0.05)$.

The dry matter yield of weeping lovegrass tended to be higher

Table 3. Error mean squares and statistical significance of differences of quality parameters of forage (whole plant) produced by Weeping Lovegrass

(W), Switchgrass (S), Kleingrass (K) and Tetrachne (T).

\begin{tabular}{|c|c|c|c|c|c|c|c|c|c|c|c|c|c|c|}
\hline \multirow{3}{*}{$\begin{array}{l}\text { Quality } \\
\text { Parameter }\end{array}$} & \multicolumn{7}{|c|}{1990} & \multirow{3}{*}{$\begin{array}{c}\text { Error } \\
\text { mean } \\
\text { squares }\end{array}$} & \multicolumn{6}{|c|}{1991} \\
\hline & \multirow{2}{*}{$\begin{array}{r}\text { Error } \\
\text { mean } \\
\text { squares } \\
\end{array}$} & \multicolumn{5}{|c|}{$\begin{array}{c}\text { Statistical significance of } \\
\text { differences }\end{array}$} & \multirow[b]{2}{*}{$\mathrm{K}-\mathrm{T}$} & & \multicolumn{6}{|c|}{$\begin{array}{c}\text { Statistical significance of } \\
\text { differences }\end{array}$} \\
\hline & & W-S & W-K & W-T & S-K & S-T & & & W-S & W-K & W-T & S-K & S-T & K-T \\
\hline $\mathrm{CP}$ & 0.36 & $* *$ & NS & $* *$ & $* *$ & $* *$ & $* *$ & 0.03 & $* *$ & *** & $* *$ & ** & *** & $* *$ \\
\hline $\begin{array}{l}\text { In vitro } \\
\text { DMD }\end{array}$ & 19.91 & NS & $* *$ & ** & $* *$ & $* *$ & NS & 11.33 & NS & ** & $* *$ & ** & $* *$ & NS \\
\hline ED & 7.41 & $* *$ & $* *$ & $* *$ & $* *$ & $* *$ & NS & 8.12 & NS & $* *$ & $* *$ & ** & $* *$ & NS \\
\hline NDF & 2.32 & NS & $* *$ & NS & $* *$ & NS & NS & 0.92 & $*$ & $* *$ & ** & $* *$ & $* *$ & NS \\
\hline $\mathrm{ADF}$ & 1.21 & $* *$ & ** & NS & ** & $* *$ & $* *$ & 0.43 & $* *$ & NS & $* *$ & ** & $* *$ & $* *$ \\
\hline Lignin & 0.21 & NS & ** & $* *$ & $* *$ & $* *$ & $* *$ & 0.38 & NS & $* *$ & $* *$ & $* *$ & $* *$ & ** \\
\hline
\end{tabular}

$*: P<0.00$ 
in winter than the other species, but its quality was generally the lowest. On the other hand, tetrachne was generally the highest in CP, IVDMD and effective degradability and the lowest in NDF, $\mathrm{ADF}$ and lignin. In addition, tetrachne had a high percentage of leaves compared to the other species.

Kleingrass forage was generally of better quality than weeping lovegrass, while dry matter yields were about $2,000 \mathrm{~kg} / \mathrm{ha}$ less (Table 2). The percentage of klcingrass leaves was the lowest of the 4 species evaluated. Kleingrass should be considered for forage production during the growing season, as it seems likely that its leaf: stem ratio would be better. Switchgrass, was the least productive species and its quality was rather low. Switchgrass stems were extremely low in quality (see Table 4). Switchgrass

Table 4. Quality parameters (means of 2 years) of leaves, stems and whole plant, produced by weeping lovegrass, switchgrass, kleingrass and tetrachne.

\begin{tabular}{|c|c|c|c|c|c|}
\hline $\begin{array}{l}\text { Quality } \\
\text { parameter }\end{array}$ & Plant fraction & $\begin{array}{l}\text { Weeping } \\
\text { lovegrass }\end{array}$ & $\begin{array}{l}\text { Switch- } \\
\text { grass }\end{array}$ & $\begin{array}{l}\text { Klein- } \\
\text { grass }\end{array}$ & Tetrachne \\
\hline $\begin{array}{l}\text { Crude } \\
\text { protein }\end{array}$ & $\begin{array}{l}\text { Leaf } \\
\text { Stem } \\
\text { Whole plant }\end{array}$ & $\begin{array}{l}4.48 \\
3.29 \\
3.83\end{array}$ & $\begin{array}{l}3.67 \\
1.83 \\
2.41\end{array}$ & $\begin{array}{r}5.91 \\
2.91 \\
3.40\end{array}$ & $\begin{array}{l}7.03 \\
4.18 \\
5.30\end{array}$ \\
\hline $\begin{array}{l}\text { In vitro } \\
\text { dry matter } \\
\text { digestibility }\end{array}$ & $\begin{array}{l}\text { Leaf } \\
\text { Stem } \\
\text { Whole plant }\end{array}$ & $\begin{array}{l}48.30 \\
41.60 \\
44.60\end{array}$ & $\begin{array}{l}49.00 \\
40.30 \\
43.30\end{array}$ & $\begin{array}{l}52.30 \\
48.40 \\
49.00\end{array}$ & $\begin{array}{l}54.40 \\
47.70 \\
50.40\end{array}$ \\
\hline $\begin{array}{l}\text { Effective } \\
\text { degradability }\end{array}$ & $\begin{array}{l}\text { Leaf } \\
\text { Stem } \\
\text { Whole plant }\end{array}$ & $\begin{array}{l}43.60 \\
36.80 \\
39.70\end{array}$ & $\begin{array}{l}60.50 \\
36.00 \\
42.10\end{array}$ & $\begin{array}{l}54.70 \\
43.60 \\
45.40\end{array}$ & $\begin{array}{l}52.10 \\
41.10 \\
45.60\end{array}$ \\
\hline $\begin{array}{l}\text { Neutral } \\
\text { detergent } \\
\text { fiber }\end{array}$ & $\begin{array}{l}\text { Leaf } \\
\text { Stem } \\
\text { Whole plant }\end{array}$ & $\begin{array}{l}76.20 \\
79.40 \\
78.00\end{array}$ & $\begin{array}{l}68.30 \\
83.30 \\
78.50\end{array}$ & $\begin{array}{l}67.90 \\
77.70 \\
75.90\end{array}$ & $\begin{array}{l}74.10 \\
78.00 \\
76.40\end{array}$ \\
\hline $\begin{array}{l}\text { Acid } \\
\text { detergent } \\
\text { fiber }\end{array}$ & $\begin{array}{l}\text { Leaf } \\
\text { Stem } \\
\text { Whole plant }\end{array}$ & $\begin{array}{l}40.00 \\
44.50 \\
42.40\end{array}$ & $\begin{array}{l}44.20 \\
49.80 \\
48.00\end{array}$ & $\begin{array}{l}38.20 \\
45.90 \\
44.60\end{array}$ & $\begin{array}{l}37.20 \\
42.30 \\
40.20\end{array}$ \\
\hline Lignin & $\begin{array}{l}\text { Leaf } \\
\text { Stem } \\
\text { Whole plant }\end{array}$ & $\begin{array}{l}5.53 \\
7.37 \\
6.53\end{array}$ & $\begin{array}{l}5.12 \\
7.21 \\
6.51\end{array}$ & $\begin{array}{l}4.62 \\
6.93 \\
6.55\end{array}$ & $\begin{array}{l}4.66 \\
6.54 \\
5.76\end{array}$ \\
\hline
\end{tabular}

leaves were low in CP content and while the IVDMD of switchgrass leaves were low, its effective degradibility (ED) was among the highest. These differences could be attributed to its comparatively low cell wall content and, within the cell wall, a higher hemicellulose: cellulose ratio (compare NDF and ADF values). The comparatively low cell wall percentage implies a relatively high cell content, which is highly soluble and degradable in the rumen. The high content of hemicellulose in the cell wall might have also contributed to the ED of leaves. Stritzler (1988) has shown that hemicellulose is digested at a higher rate and extent than cellulose.

\section{Comparison Between Harvest Dates}

Only the samples of the first harvest date were of significantly higher quality. Although there was a trend toward lower dry matter yields with successive harvest dates, these differences were not significant (Table 5). There were no significant differences in leaf percentage, and $\mathrm{CP}$ content among harvest dates. The IVDMD and effective degradability (ED) were not significantly different among harvest dates in 1990, but in 1991, harvest dates 1 and 2 had higher leaf IVDMD than 3,4 , and 5 and higher stem and whole plant fraction ED.
Table 5. Dry matter yield in (kg/ha) of whole plant, percentage of leaves and Leaf:stem ratio, on dry matter basis on each harvest date (means of the 4 grasses evaluated) over the 2 years.

\begin{tabular}{|c|c|c|c|c|c|c|}
\hline \multirow{3}{*}{$\begin{array}{l}\text { Harvest } \\
\text { date }\end{array}$} & \multicolumn{6}{|c|}{ Year } \\
\hline & \multicolumn{3}{|c|}{1990} & \multicolumn{3}{|c|}{1991} \\
\hline & Dry matter & Leaves & Leaf:stem & Dry matter & \% Leave & Leaf:stem \\
\hline & (kg/ha) & (\%) & & (kg/ha) & $(\%)$ & \\
\hline 1 & $8012^{3}$ & $31.6^{\mathrm{a}}$ & 0.46 & $8179^{a}$ & $37.8^{a}$ & 0.61 \\
\hline 2 & $7128^{a}$ & $33.4^{\mathrm{a}}$ & 0.50 & $8500^{a}$ & $35.6^{\mathrm{a}}$ & 0.55 \\
\hline 3 & $6536^{a}$ & $30.1^{n}$ & 0.43 & $8119^{3}$ & $34.1^{3}$ & 0.52 \\
\hline 4 & $6592^{\mathrm{a}}$ & $33.6^{2}$ & 0.51 & $7425^{a}$ & $33.9^{\mathrm{a}}$ & 0.51 \\
\hline 5 & $6597^{\mathrm{a}}$ & $32.9^{\mathrm{a}}$ & 0.49 & $7895^{3}$ & $35.0^{2}$ & 0.54 \\
\hline
\end{tabular}

Values within a colurn, followed by different letter, are significantly different $(P<0.05)$.

Stem digestibility for tetrachne and kleingrass range from 50 to 55 early in the winter season to between 45 and $50 \%$ by the end of the winter period. The NDF, ADF, and lignin content of leaves, stems and whole plant fractions tended to increase with harvest date, in both years, but significant differences occurred $(\mathrm{P}<0.05)$ only between harvest dates 1 vs. 3,4 , and 5 .

The partitioning of aboveground biomass between stems and leaves has been reported recently (Ugherughe 1986, Coyne and Bradford 1986, Dabo et al 1987, Nordkvist et al 1987, McBee and Miller 1990). It is well known that the parts of the plant differ in quality, and that the nutritive value of leaves is generally higher than stems. As the ruminant seldom eats whole plants, whole plant analyses underestimate the nutritional value of forages. Stritzler et al (1986), offered forage of old world bluestem (Bothriochloa bladhii), a warm-season grass to ewes, ad libitum; the leaf: stem ratio of the offered forage was about $1: 4$, while the ratio was $1: 11$ in the refused feed, demonstrating that the animal preferentially consumes leaves. In the present study, the quality parameters were measured on the leaves, stems and whole plant. As expected (Terry and Tilley 1964), the nutritive valuc of leaves was higher than that of stems; these data may help to explain unexpected liveweight gain in animals grazing warm-season grasses (Reid et al 1988; Mullahey et al 1992), because the chemical analyses of whole plant samples show a nutritive value only enough to maintenance, while, due to selective grazing of leaves, the diet consumed by the animals is much higher in quality than that measured in the laboratory.

Numerous experiments have been carried out with weeping lovegrass (Fernández et al 1991), but no information is available in the Argentine literature concerning the 2 species of the genus Panicum evaluated in this study. This appears to be the first data on forage yield and quality produced by Panicum virgatum and Panicum coloratum in Argentina. The first study with Tetrachne dregei was recently reported (Frasinelli et al 1993).

The 2 species of the genus Panicum are well known in the United States of America, where they are important components of the grazing systems of the Southern Great Plains and other regions (Anderson and Matches 1983; Sanderson, 1992). Kleingrass forage is also being evaluated in other parts of the world (Minson 1971; Bansal et al 1986). However, most studies were on growing season forage (Jung et al 1990). In these studies where comparisons with our data could be made, their results agreed with ours and confirmed that they are high yielding species (Lugg et al 1987), with a low leaf: stem ratio (Sanderson 1992) and more nutritive leaves than stems (George and Obermann 1989; Mullahey et al 1992). 
Tetrachne dregei is a native grass of South Africa, where it is not an important component of pastures, but only one of the many species of the natural grasslands (Covas 1974). To our knowledge, no information about this species, except for botanical description, is available in the literature.

\section{Conclusions}

Our results confirm earlier information (Rabotnikof et al 1986a, $1986 \mathrm{~b}$ ), that some warm-season grasses introduced to the semiarid Pampean Region of Argentina may be an alternative to weeping lovegrass as standing deferred forage to grazing beef cows. The results obtained in this study clearly showed that Tetrachne dregei (tetrachne), during the winter, had the highest nutritional value of those evaluated. Tetrachne had, generally, the highest CP, IVDMD and effective degradibility (ED) content, and the lowest content of NDF, ADF, and lignin. In addition, the yield and percentage of leaves were good when compared to the other species.

Panicum coloratum (kleingrass) was the second most productive and nutritious species, with high dry matter yield and forage quality values higher than the standard, Eragrostis curvula cv. Tanganyka (weeping lovegrass). Panicum virgatum $\mathrm{cv}$. Pathfinder (switchgrass) was generally the least productive species in this study and its nutritive value was low. Early winter forage was generally of highest quality, forage quality declined most rapidly in early winter, thereafter the quality tended to stabilize in nutritive value.

In all the species under study, the quality of the leaves was much higher than that of stems. Tetrachne had the highest leaf:stem ratio, and in addition, the nutritive value of both the leaves and stems of this warm-season grass tended to be higher than the other species studied. The dry matter yield of tetrachne, although lower than the yield of weeping lovegrass, was relatively high. Tetrachne dregei is, therefore, a promising warm-season grass, that may provide more nutritious forage during winter for grazing systems in the semi-arid Pampean Region of Argentina.

\section{Literature Cited}

Alexander, R.H. and M. MIcGowan. 1966. The routine determination of in vitro digestibility of organic matter in forages. An investigation of the problems associated with continuous large scale operation. J. Brit. Grassl. Soc. 21: 140-147.

Anderson, B. and A.G. Matches. 1983. Forage yield, quality, and persistence of switchgrass and caucasian bluestem. Agron. J. 75: 119-124.

Bansal, S.K., C.B. Johri, and G.S. Rai. 1986: Panicum colorattm L., a promising fodder for stallfed goats. Indian J. Anim. Sci. 56: 1111-1112.

Christian, K.1971. The detergent method for total lignin determination in forages. Fed.Sta. Res. Div. Pl. Ind., CSIRO, 10:29-34.

Covas, G.1974. Los pastos sudafricanos en relación a la forrajicultura en La Pampa, con especial referencia al Pasto llorón (Eragrostis curvula) (in Spanish).Simposio de Pasto llorón en la Provincia de La Pampa, Argentina, pp. 1-10.

Covas, G. 1982. Potencial y limitaciones de los recursos forrajeros actuales y de aquellos en vías de experimentación en la Región Pampeana Semiárida (in Spanish).Actas de las Primeras Jornadas Técnicas sobre Producción Animal en la Región Pampeana Semiárida.Fac.Agron., U.N.L.Pampa, Argentina, pp. 13-31.

Coyne, P.I. and J.A. Bradford. 1986. Biomass partitioning in "caucasian" and WW-Spar old world bluestems. J. Range Manage. 39: 303-310.
Dabo, S.M., C.M. Taliaferro, S.W. Coleman, F.P. Horn, and P.L. Claypool. 1987. Yield and digestibility of old world bluestem grasses as affected by cultivar, plant part, and maturity. J.Range Manage. 40: 10-15.

Fernández, O.A., R.E. Brevedan, and A.O. Gargano. 1991. El pasto llorón. Su biología y manejo (in Spanish). Cerzos and Universidad Nacional del Sur ed., Bahía Blanca, Argentina.

Frasinelli, C.A., J. Veneciano, M. Funes, and A. Marchi. 1993. Evaluacion de Tetrachne dregei (Nees) bajo condiciones de diferimiento (in Spanish).Revista Argentina de Producción Animal 13:51-52 (Abstract)

George, J.R. and D. Obermann. 1989. Spring defoliation to improve summer supply and quality of switchgrass. Agron. J. 81: 47-52.

Goering, H.K. and P.J. Van Soest. 1970. Forage fiber analysis (apparatus, reagents, procedures and some applications). Agr. Handb. No. 379 A.R.S., Dep. Agr., U.S.A.

Jung, G.A., J.A. Shaffer, W.L. Stout, and M.T. Panciera. 1990. Warmseason grass diversity in yield, plant morphology, and nitrogen concentration and removal in Northeastern U.S.A. Agron. J. 82:21-26.

Lugg, D.G., F. Smith, and J.F. Gómez. 1987. Performance of warm-season perennial grasses in New Mexico. Agr. Exp.Sta., Bull 729, New Mexico State Univ., N.M.

McBee, G.G. and F.R. Miller. 1990. Carbohydrate and lignin partitioning in sorghum stems and blades. Agron. J. 82: 687-690.

McDonald, I. 1981. A revised model for the estimation of protein degradability in the rumen. J. Agr. Sci. (Camb.) 96: 25I-252.

Minson, D.J. 1971. Influence of lignin and silicon on a summative system for assessing the organic matter digestibility of Panicum. Australian J. Agr. Res. 22: 589-598.

Mullahey, J.J., S.S. Waller, K.J. Moore, L.E. Moser, and T.J. Klopfenstein. 1992. In situ ruminal protein degradation of switchgrass and smooth bromegrass.Agron. J. 84: 183-188.

Nordkvist, E., H. Graham, and P. Aman. 1987. Degradation in vitro and in sacco of red clover leaves and stems. Anim. Feed Sci. Tech. 17: 295-304.

Rabotnikof, C.M., O.A. Hernández, N.P. Stritzler, M. Gallardo, E. Funes, and C.A. Villar. 1986a. Evaluación de especies forrajeras estivales en la Región Pampeana Semiárida. I.Determinación de pared celular, lignina y desaparición de materia seca en bolsitas de Bothriochloa intermedia, Eragrostis curvula, Digitaria eriantha, Panicum antidotale y Setaria leiantha bajo condiciones de diferimiento (in Spanish). Revista Argentina de Producción Animal 6: 47-56.

Rabotnikof, C.M.; N.P. Stritzler, and O.A. Hernández. 1986b. Evaluación de especies forrajeras estivales en la Región Pampeana Semiárida. II. Determinación de producción de materia seca, persistencia, proteína y digestibilidad in vitro de Bothriochloa intermedia, Digitaria eriantha, Setaria leiantha, Eragrostis curvula y Panicum antidotale bajo condiciones de diferimiento (in Spanish).Revista Argentina de Producción Animal 6: 57-66.

Reid, R.L.; G.A. Jung, and D.W. Allison. 1988. Nutritive quality of warm-season grasses in the Northeast. Agr. Forestry Exp. Sta., Bull. 699, West Virginia Univ., W.Va.

Sanderson, M.A. 1992. Morphological development of switchgrass and kleingrass. Agron. J. 84:415-419.

Sokal, R.R. and F.J. Rohlf. 1979. Biometría. Principios y métodos estadísticos en la investigación biológica. (in Spanish) Blume ed., Madrid, Spain.

Stritzler, N.P. 1988. The effect of nitrogen and energy supplementation on the digestion of non-starch polysaccharides and microbial activity in the rumen of cows fed fibre-rich diets. Ph.D. Diss., The Royal Vet. \& Agric. Univ., Copenhagen, Denmark.

Stritzler, N.P., C.M. Rabotnikof, H. Lorda, and A. Pordomingo. 1986. Evaluación de especies forrajeras estivales en la Región Pampeana Semiárida. III. Digestibilidad y consumo de Digitaria eriantha y Bothriochloa intermedia bajo condiciones de diferimiento (in Spanish).Revista Argentina de Producción Animal. 6: 67-72.

Terry, R.A. and J.M.A. Tilley. 1964. The digestibility of the leaves and stems of perennial ryegrass, cocksfoot, timothy, tall fescue and sainfoin as measured by an in vitro procedure. J. Brit. Grassl. Soc. 19:288-305.

Tilley, J.M.A. and R.A. Terry. 1963. A two stage technique for the in vitro digestion of forage crops. J.Brit. Grassl. Soc. 18:104-111.

Ugherughe, P.O. (1986): Relationship between digestibility of Bromus inermis plant parts. J. Agron. Crop Sci. 157: 136-143. 